\title{
The role of circulating hepatitis B antigen/antibody immune complexes in the pathogenesis of vascular and hepatic manifestations in polyarteritis nodosa
}

\author{
CHRISTIAN G. TREPO, ARIE J. ZUCKERMAN, RICHARD C. BIRD, AND \\ ALFRED M. PRINCE
}

From the University of Lyons, New York Blood Center and Cornell University, and the London School of Hygiene and Tropical Medicine

SYNOPSIS To investigate further the role of hepatitis $\mathrm{B}$ antigen (HBs Ag) and specific immune complexes in polyarteritis, sera from 55 histologically confirmed cases were tested for the presence of hepatitis B antigen-associated particles and hepatitis B-antibody (anti HBs) by solid phase radioimmunoassay, electron microscopy, and passive haemagglutination. Results of these findings have been correlated with the clinical course of the disease.

$\mathrm{HBs} \mathrm{Ag}$ was detected in 30 patients $(54.5 \%)$ and anti $\mathrm{HBs}$ in 13/45 (28\%). Subtyping in 20 patients revealed that 11 were $\mathrm{Y}$ and $9 \mathrm{D}$. Thirty-seven cases $(69 \%)$ demonstrated either $\mathrm{HBs} \mathrm{Ag}$ or anti $\mathrm{HBs}$ and $5 / 45(11 \%)$ had both. Electron microscopic examination showed $20 \mathrm{~nm}$ spherical and tubular particles in sera of 20/27 patients with $42 \mathrm{~nm}$ particles in 11 cases and clumped particles in $12(60 \%)$.

No correlation was found between detection of immune complexes and liver disease whereas the presence of coexisting hepatitis $\mathbf{B}$ antigen and antibody or aggregated particles was restricted to cases of active vasculitis. Seroconversion or the presence of hepatitis B antibody alone was associated with improved prognosis. Circulating hepatitis B antigen antibody complexes may be responsible for vasculitis or polyarteritis but do not appear to be pathogenic for the liver.

Studies by several authors have suggested that chronic hepatitis $\mathbf{B}$ infection could cause a proportion of cases of polyarteritis nodosa (Trepo and Thivolet, 1970a and b; Gocke, Hsu, Morgan, Bombardieri, Lockshin, and Christian, 1970; Baker, Kaplan, Benz, Sidel, and Wolfe, 1972; Martini, Strohmeyer, and Sodomann, 1972). Hepatitis B antigen has now been detected in $22(40 \%)$ of 53 cases examined for the presence of this antigen in four different centres (Trepo, 1972; Gocke, Hsu, Morgan, Bombardieri, Lockshin, and Christian, 1971; Ziff, 1971; Kohler, 1973). However, even if the frequency of an association between polyarteritis and persistent HBs antigenaemia is thus now established, the immunopathogenic mechanism involved still remains obscure. The simplest hypothesis would be to consider HBs Ag-associated polyarteritis nodosa as an immune complex disease involving $\mathrm{HBs} \mathrm{Ag}$ /anti HBs circulating complexes (Trepo and Thivolet, 1970a and b; Gocke et al, 1970).

Received for publication 22 August 1974.
Gocke et al (1970) reported immunofluorescence and density gradient experiments which were interpreted as consistent with this type of mechanism. However, Prince and Trepo (1971) failed to detect circulating immune complexes in six out of seven cases analysed by sensitive haemagglutination, haemagglutination inhibition, and ultracentrifugation techniques. Furthermore, these authors emphasized the fact that circulating HBs Ag/anti HBs complexes could be found in many chronic HBs Ag carriers without evident vasculitis or liver disease. Similar conflicting data have also been reported by others (Gerber, Brodin, Steinberg, Vernace, Yang, and Paronetto, 1972; Heathcote, Dudley, and Sherlock, 1972; Nowoslawski, Krawczynski, Brzosko, and Madalinski, 1972; Couleru, German, Bousquet, and Sarrazin 1972). In the present study we have further investigated thesequestions by the use of electron microscopy as well as the more sensitive of the serological assays now available, and have attempted to correlate our findings with the clinical course of the disease. 


\section{Materials and Methods}

\section{PATIENTS}

Sera were obtained from 55 histologically confirmed cases of polyarteritis nodosa observed in Lyons or referred to this centre. Detailed clinical features of many of these patients have been described elsewhere (Trepo, 1971; Trepo, Thivolet, and Lambert, 1972). Patients found to be positive for HBs Ag or anti HBs were subsequently followed and serial serum specimens were obtained. The presence or absence of liver disease was determined by routine clinical and liver function tests, as well as by liver biopsy examinations in 18 cases.

The activity of the vascular disease in the cases studied was classified as follows:

\section{Active}

Twenty-three patients with at least five of the following signs or symptoms: fever, weight loss $\geq 5 \mathrm{~kg}$, arthralgia, myalgia, polyneuritis, glomerulonephritis, hypertension, leucocytosis (greater than $10000 \mathrm{wbc} / \mathrm{mm}^{3}$ with more than $75 \%$ polynuclear leucocytes), relapse of symptoms when steroids were withdrawn.

\section{Quiescent}

Six patients without immunosuppressive treatment seen more than one year after onset with stabilized disease characterized by the absence of fever, arthralgia, myalgia, or recent significant weight loss and with an erythrocyte sedimentation rate less than $25 \%$ and a leucocyte concentration $\leq 9000 \mathrm{~mm}^{3}$.

\section{Apparently recovered}

This group consisted of three patients in whom all clinical signs or symptoms as well as significant laboratory abnormalities had disappeared for 16 months or more (16 to 64 months) without treatment.

\section{SEROLOGICAL METHODS}

Serum specimens were shipped frozen in dry ice to The New York Blood Center where they were tested by haemagglutination for the presence of anti HBs (Prince, Brotman, and Ikram, 1972) and by radioimmunoassay for HBs Ag (Prince, Brotman, Jass, and Ikram, 1973) using Ausria kits supplied by Abbott Laboratories. The specificity of positive results obtained only by radioimmunoassay was confirmed by repeating the test after neutralization with known human anti-HBs-positive sera (Prince et al, 1973). Subtyping of HBs Ag for Y (ay) or $D(a d)$ specificity was performed by haemagglutination inhibition using red cells coated with either ad or ay antigen and tested versus adsorbed antiserum that is more than $90 \%$ monospecific for $\mathrm{Y}$ or $\mathrm{D}$ (Prince et al, 1972).

Forty-five serum samples from 27 patients with polyarteritis nodosa were sent frozen in dry ice to London for electron microscopic studies. Specimens were processed and examined after negative staining by methods which have been described elsewhere (Zuckerman, 1970). Negative stain preparations were made in carbon and formvar-coated smethurst no. 400 copper grids using $4 \%$ ammonium molybdate (pH 5.3) as the contrast stain. They were viewed in a GEC EM 801 microscope.

\section{Results}

SEROLOGY

$\mathrm{HBs} \mathrm{Ag}$ was found in 30 out of 55 patients. Chronic HBs antigenaemia remained detectable in all serial specimens except in two cases, in which disappearance of $\mathrm{HBs} \mathrm{Ag}$ was followed by the appearance of a low level of HB antibody (titres $1: 8$ ). Anti HBs only was detected in eight more cases at a titre of $1: 8$ or greater by haemagglutination. The simultaneous presence of $\mathrm{HBs} \mathrm{Ag}$ and anti HBs was detected transiently in five of 45 cases in which tests for both antigen and antibody were carried out. Subtyping performed by haemagglutination inhibition in 20 cases revealed that 11 patients were $Y$ and nine $\bar{c}$ others D.

\begin{tabular}{llll}
\hline Finding & Technique & $\begin{array}{l}\text { No. of Cases } \\
\text { Tested }\end{array}$ & $\begin{array}{l}\text { No. of Cases } \\
\text { Positive }\end{array}$ \\
\hline HBs Ag & RIA & 55 & $30(54.5 \%)$ \\
Anti HBs $\geqslant 1 / 8$ & HA & $45^{2}$ & $13(28 \%)$ \\
HBs Ag or anti HBs & RIA HA & 55 & $38(69 \%)$ \\
HBs Ag + Anti HBs & RIA & $45^{2}$ & $5(11 \%)$ \\
$\geqslant 1: 8$ & HA & & $8(17.7 \%)$ \\
$\begin{array}{l}\text { Anti HBs } \geqslant 1: 8 \\
\text { without HBs Ag }\end{array}$ & RIA & $45^{2}$ & 8 \\
\hline
\end{tabular}

Table I Serological results obtained in 55 cases of polyarteritis nodosa

${ }^{1}$ RIA = radioimmunoassay: $\mathbf{H A}=$ haemagglutination.

${ }^{2}$ In 10 cases no specimen was available for anti HBs detection.

\section{ELECTRON MICROSCOPY}

Electron microscopic studies performed on 45 serum samples from 27 patients revealed particles suggestive of $\mathrm{HBs} \mathrm{Ag}$ in 34 specimens from 20 cases. The 20 patients in whom the particles were seen had all been found to have circulating HBs Ag. No particles were detected in any of the patients with antibody only. All three morphological types of particle (21) were observed, $20 \mathrm{~nm}$ spherical particles, filaments, and $42 \mathrm{~nm}$ Dane particles (fig 1). Twenty $\mathrm{nm}$ spherical 


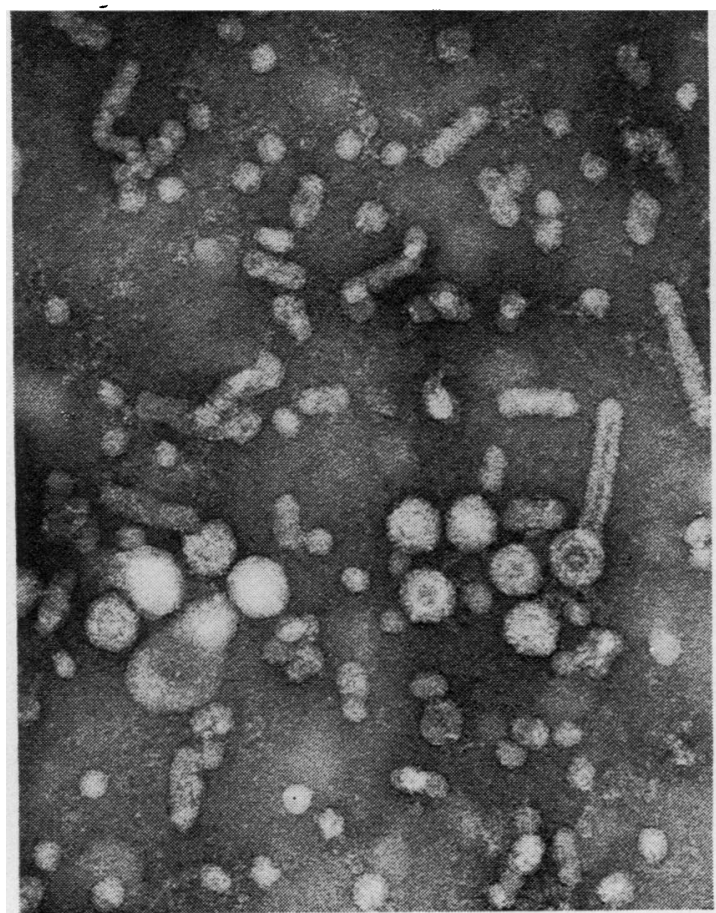

Fig 1 A typical area of a grid square prepared from serum LSH 16131-A/10872. All three morphological types of particles are present: $20-30 \mathrm{~nm}$ particles, filaments varying in length, and $42 \mathrm{~nm}$ Dane particles, some with attached flaments. $\times 126000$

\begin{tabular}{lcl}
\hline Findings & $\begin{array}{l}\text { No. Cases } \\
\text { Positive }\end{array}$ & $\begin{array}{l}\text { No. Sera } \\
\text { Positive }\end{array}$ \\
\hline 20-30 nm particles and filaments & $20(74 \%)$ & $34(75 \%)$ \\
Above and 42 nm particles & $11(41 \%)$ & $17(37 \%)$ \\
Scattered particles only & $8(29 \%)$ & $20(44 \%)$ \\
Scattered particles and clumps & $12(44 \%)$ & $14(31 \%)$
\end{tabular}

Table II Electron microscopic observations in 45 sera from 27 cases of polyarteritis nodosa

particles and filaments were always found together, filaments being less numerous than $20-30 \mathrm{~nm}$ particles. The $42 \mathrm{~nm}$ particles were present in 11 of 20 cases in which the other particles were found.

Careful study of the distribution of particles revealed that only scattered particles could be observed in 20 sera from eight patients (figure 2) whereas aggregates of different size, many of them including $42 \mathrm{~nm}$ particles (figure 3) were observed in 14 samples from the 12 other patients studied. The three serum samples examined by electron microscopy in which both HBs Ag and anti HBs (haemag- glutination titre $\geq 1: 8$ ) were present revealed clumped particles; however, only three out of 12 sera with clumps had demonstrable antibody.

CORRELATION OF SEROLOGICAL AND ELECTRON MICROSCOPIC DATA WITH THE COURSE OF THE DISEASE (TABLES III AND IV)

Both high and low HBs Ag titres were found associated with severe polyarteritis and no difference in the course could be observed between patients bearing either $Y$ or $D$ specificity. Serial samples were examined from 10 cases with a prolonged course and recurrent illness. In three cases the titre of $\mathrm{HBs} \mathbf{A g}$ progressively increased from the onset of the disease to a constant high titre under combined steroid and azathioprine therapy with concurrent clinical improvement. In three others seen later in the course a steady high titre of $\mathrm{HBs} \mathrm{Ag}$ was observed. In two patients the $\mathrm{HBs} \mathrm{Ag}$ titre dropped during a period of clinical exacerbation being only detectable by radioimmunoassay in one.

Dramatic clinical improvement leading to complete clinical remission was followed by the total disappearance of $\mathrm{HBs} \mathrm{Ag}$ with the appearance of a low level of anti HBs in two patients.

Seven of the eight patients with anti HBs were seen either during a quiescent phase of the disease (four patients' titre $1: 64,1: 128,1: 512,1: 32000$ ) or after complete clinical remission for more than two years (three patients' titres 1:8, 1:8, and 1:16) (table III).

Out of 23 patients with active illness 18 were found to have circulating $\mathrm{HBs} \mathrm{Ag}(78.2 \%)$, one anti HBs, and four (17.3\%) both $\mathrm{HBs} \mathrm{Ag}$ with transient anti HBs at a titre $\geq 1: 8$, at the onset of vasculitis (table III). Electron microscopic examination revealed clumped particles in $12 / 18(66.6 \%)$ (table IV).

\begin{tabular}{lccll}
\hline $\begin{array}{l}\text { Stage of } \\
\text { Disease }\end{array}$ & $\begin{array}{l}\text { No. of Cases } \\
\text { Studied Cases with } \\
\text { HBs Ag only }\end{array}$ & $\begin{array}{l}\text { Cases with } \\
\text { Anti HBs } \\
\geqslant 1: 8 \text { Only }\end{array}$ & $\begin{array}{l}\text { Cases with } \\
\text { HBs Ag and } \\
\text { Anti HBs } \\
\geqslant 1: 8\end{array}$ \\
\hline $\begin{array}{l}\text { Active } \\
\begin{array}{l}\text { Quiescent } \\
\text { Apparently } \\
\text { recovered }\end{array}\end{array}$ & 23 & $18(78.2 \%)^{1}$ & $1^{2}(4 \%)$ & $4^{3}(17 \cdot 3 \%)$ \\
\hline
\end{tabular}

Table III Relationship between serological findings and stage of disease in 32 cases associated with $\mathrm{HBs} \mathrm{Ag}$ and/or anti $\mathrm{HBS}$

${ }^{1} \chi^{2}=1 \cdot 687, \mathrm{P}$-non-significant

$x^{2}=3 \cdot 712, \mathrm{P}-$ on the borderline of significance

$x^{2}=0.036, P-$ non-significant

Of six stabilized patients seen during a quiescent phase of the disease, four had demonstrableanti HBs (table III). No clumps were observed in this group and only one had scanty Dane particles (table IV). 


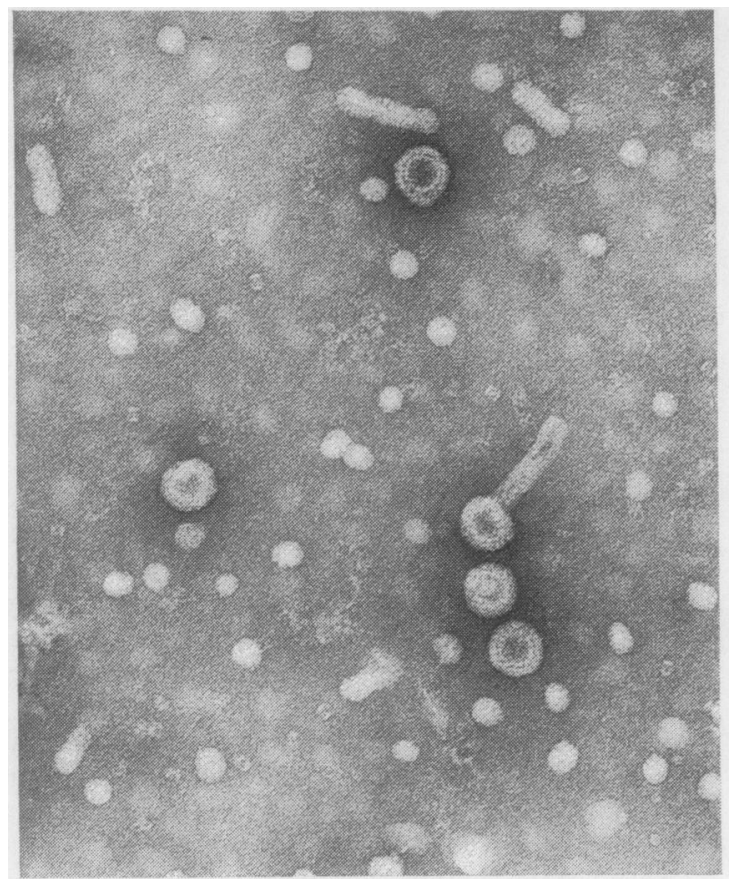

Fig 2 Scattered particles only were observed in 20 sera from eight patients—serum LSH 16133-A/10556. $\times 126000$

\begin{tabular}{|c|c|c|c|}
\hline Stage of Disease & $\begin{array}{l}\text { No. of Cases } \\
\text { with } 20 \mathrm{~nm} \text { and } \\
\text { Filaments }\end{array}$ & $\begin{array}{l}\text { Proportion of } \\
\text { Cases with } \\
\text { Particles }\end{array}$ & $\begin{array}{l}\text { Proportion of } \\
\text { Cases with } \\
\text { Clumps }\end{array}$ \\
\hline \multirow{2}{*}{$\begin{array}{l}\text { Active } \\
\text { Quiescent } \\
\text { Apparently } \\
\quad \text { recovered }\end{array}$} & $\begin{array}{r}18 \\
2\end{array}$ & $\begin{array}{c}10 / 18 \\
1 / 2\end{array}$ & $\begin{array}{c}12 / 18 \\
0 / 2\end{array}$ \\
\hline & 0 & $\mathbf{0}$ & 0 \\
\hline
\end{tabular}

Table IV Relationship between electron microscopic observations and stage of disease in 20 cases of polyarteritis nodosa associated with $\mathrm{HBs} \mathrm{Ag}$

All the three apparently recovered patients were found to have anti HBs at low titre $(1: 8)$. Clumped particles were observed in association with histologically confirmed chronic hepatitis in seven cases (five persistent and two aggressive), liver cirrhosis in one, and no clinical or laboratory evidence of liver dysfunction in four, with histologically confirmed normal liver in two of these. Transaminases, bilirubin, and alkaline phosphatase were within normal limits in seven of 12 of the patients with clumped particles.

\section{Discussion}

The detection of $\mathrm{HBs} \mathrm{Ag}$ in $54.5 \%$ of cases of poly-

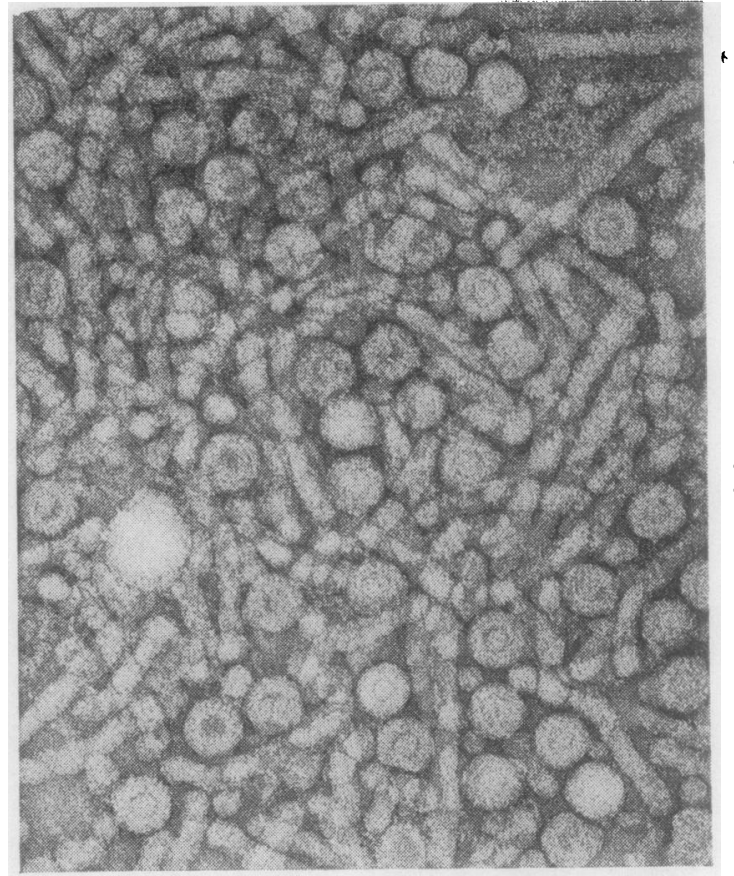

Fig 3 Part of a large clump composed of all three morphological types of particles as seen transiently in serial serum samples of two cases. $\times 126000$

arteritis nodosa clearly indicates a significant relationship, since this is an even higher frequency than that found by the same radioimmunoassay technique in 216 cases (47\%) of acute hepatitis in adults from Lyons (Trepo, Trepo, Ortiz, Monier, and Sepetjian, 1973).

Both $\mathrm{Y}$ and $\mathrm{D}$ subtypes were equally frequent in the cases of polyarteritis nodosa tested, and were not associated with differences in clinical course, suggesting again that subtype antigens may represent seroepidemiological markers devoid of specific biological properties (LeBouvier, 1973).

The significance of anti HBs in the absence of detectable $\mathrm{HBs} \mathrm{Ag}$ in eight of $45(17.7 \%)$ of cases of polyarteritis nodosa is more difficult to interpret since a similar frequency of anti HBs has been observed in several population groups (Lander, Alter, and Purcell, 1971).

However, it is noteworthy that the presence of anti HBs alone was shown to follow termination of HBs antigenaemia with dramatic improvement in two of these cases and to be associated with quiescent disease in five others. It may thus be suspected that anti HBs in those cases reflect seroconversion and is beneficial consequences in $\mathrm{HBs} \mathrm{Ag}$-associated 
polyarteritis rather than past and unrelated hepatitis $B$ virus infection.

It is likely that the $42 \mathrm{~nm}$ particles represent the virion of type $B$ hepatitis. Their high proportion in these patients is striking, since in the more usual HBs Ag-containing sera the number of $42 \mathrm{~nm}$ particles is just within the range of detectability in the electron microscope (Almeida, 1971).

Since most of our patients received immunosuppressive therapy (steroid with or without azathioprine) a possible effect of this therapy on the proportion of $42 \mathrm{~nm}$ particles cannot be ruled out.

Almeida and Waterson (1969) emphasized that electron microscopic examination of $\mathrm{HBs} \mathrm{Ag}$ associated particles in serum may provide a useful tool for the detection of circulating $\mathrm{HBs} \mathrm{Ag} /$ anti HBs immune complexes. They also suggest that the presence of such complexes as well as their composition could account for the different clinical patterns of hepatitis type B. Clumps of HBs Agassociated particles have been considered by most authors to represent immune complexes.

In this series clumps were found in all three samples examined by electron microscopy in which both $\mathrm{HBs} \mathrm{Ag}$ with anti $\mathrm{HBs}$ were present. If we accept clumps as an index of $\mathrm{HBs} \mathrm{Ag} /$ anti $\mathrm{HBs}$ complexes, electron microscopy would appear to be more sensitive for the detection of such immune complexes than the serological techniques presently used. In the present study clumps as well as coexisting $\mathrm{HBs} \mathrm{Ag}$ with anti $\mathrm{HBs}$ were restricted to cases with signs of active vasculitis.

Although the numbers in the quiescent and apparently recovered groups are too small to provide statistically significant results, these findings suggest that HBs Ag/anti HBs complexes may be related to the pathogenic mechanism.

The observation that the HBs Ag titre may drop during exacerbation of illness and that 'recovery' may coincide with the disappearance of $\mathrm{HBs} \mathrm{Ag}$ and the appearance of anti HBs is also compatible with the hypothesis of an immune complex mechanism for the pathogenesis of polyarteritis nodosa.

The presence of vasculitis with fibrinoid necrosis, polymorphonuclear infiltrate, and the indentification by immunofluorescence of $\mathrm{HBs} \mathrm{Ag}$ with immunoglobulins and complement in recent exudative hyaline and fibrinoid lesions supports this suggestion (Nowoslawski et al, 1972). It is not clear why circulating HBs Ag complexes are not found in a greater proportion of cases with the techniques used, and why only a small proportion of patients with circulating $\mathrm{HBs} \mathrm{Ag} /$ anti $\mathrm{HBs}$ immune complexes develop polyarteritis.

The factors that determine the localization and inflammatory effects of immune complexes respon- sible for the development of vasculitis or glomerulonephritis are only beginning to be appreciated. It appears that complexes are pathogenic only if of a certain size and definite antigen/antibody ratio. The nature as well as the amount of antibody is critical in this regard (Cochrane and Koffler, 1973).

We failed to find a significant association between the presence or absence of aggregated particles and evidence of liver disease. In our cases of polyarteritis nodosa, hepatitis was usually found to be present at the onset of the disease but was mild and resolved almost totally in more than half of the cases despite continued active vasculitis. This dissociation suggests that hepatitis and vascular lesions may be mediated through different immunopathogenic mechanisms. The same dissociation is observed in the serumsickness-like syndrome which precedes the onset of liver injury in acute hepatitis type B. Sequential complement analyses suggested that this syndrome could result from the formation of $\mathrm{HBs} \mathrm{Ag} /$ anti $\mathrm{HBs}$ complexes (Alpert, Isselbacher, and Schur, 1971). Thus circulating immune complexes may be crucial pathogenic factors in hepatitis B-associated polyarthritis, glomerulonephritis (Knieser, Jenis, Lowenthal, Bancroft, Burns, and Shalhoub, 1974), and vaculitis; however, the available evidence suggests that they are not able to induce active liver disease.

A cell-mediated immune response to so far undefined antigenic specificities, possible membrane antigens on the surface of virus-infected liver cells, may be involved (Prince and Trepo, 1971; Dudley, Fox, and Sherlock, 1972; Popper and MacKay, 1972).

Since this paper was submitted for publication we have investigated the sera of polyarteitis patients for the presence of the antibody directed against the recently identified hepatitis $B$ core antigen. This antibody (anti $\mathrm{HBc}$ ) was detected in $35 / 38$ of the cases with either HBs or anti HBs by a modified indirect immunofluorescence technique confirming actual or recent replication of hepatitis $B$ virus in those cases.

This study was supported by NIH grant no. 09011 . Dr Trepo is the recipient of a Health International postdoctoral fellowship, grant no. TWO-1864-01. The work at the London School of Hygiene and Tropical Medicine was supported by generous grants from the Medical Research Council, the WHO, Dr W. Charles Cockburn, Pfizer Ltd, and the Wellcome Trust. Dr Prince is a career scientist of the Health Research Council of the City of New York (contract I-533).

\section{References}

Almeida, J. D. (1972). Individual morphological variations seen in 
Australia antigen positive sera. Amer. J. Dis. Child., 123, 303-309.

Almeida, J. D., and Waterson, A. P. (1969). Immune complexes in hepatitis. Lancet, 2, 983-986.

Alpert, E., Isselbacher, K. J., and Schur, P. H. (1971). The pathogenesis of arthritis associated with viral hepatitis complement component studies. New Engl. J. Med., 285, 185-189.

Baker, A. L., Kaplan, M. M., Benz, W. C., Sidel, J. S., and Wolfe, H. J. (1972). Polyarteritis associated with Australia antigen positive hepatitis. Gastroenterology, 62, 105-110.

Cochrane, C., and Koffler, D. (1973). Immune complex disease. Advanc. Immunol., 16, 185-264.

Couleru, O., German, A., Bousquet, O., and Sarrazin, A. (1972) Immune complexes in large particles of Australia antigen in polyarteritis. Lancet, 1, 445-446.

Dudley, F. J., Fox, R. A., and Sherlock, S. (1972). Cellular immunity and hepatitis associated Australia antigen liver disease. Lancet, 1, 723-726.

Gerber, M. A., Brodin, A., Steinberg, D., Vernace, S., Yang, C. P., and Paronetto, F. (1972). Periarteritis nodosa, Australia antigen and lymphatic leukemia. New Engl. J. Med., 286, 14-17.

Gocke, D. J., Hsu, K., Morgan, C., Bombardieri, S., Lockshin, M. and Christian, C. L. (1970). Association between polyarteritis and Australia antigen. Lancet, 2, 1149-1153.

Gocke, D. J., Hsu, K., Morgan, C., Bombardieri, S., Lockshin, M., and Christian, C. L. (1971). Vasculitis in association with Australia antigen. $J$. exp. Med., 134, 330s-336s.

Heathcote. E. J. L., Dudley, F. J., and Sherlock, S. (1972). The association of polyarteritis and Australia antigen. Digestion, 6, 280-281.

Kohler, P. F. (1973). Clinical immune complex disease: manifestation in systemic lupus erythematosus and hepatitis B virus infection. Medicine (Baltimore), 52, 419-429.

Knieser, M. R., Jenis, E. H., Lowenthal, D. T., Bancroft, W. H., Burns, W., and Shalhoub, R. (1974). Pathogenesis of renal disease associated with viral hepatitis. Arch. Path., 97, 193-200.

Lander, J. J., Alter, H. J., and Purcell, R. H. (1971). Frequency of antibody to hepatitis-associated antigen as measured by a new radioimmunoassay technique. $J$. Immunol., 106, 1166-1171.

LeBouvier, G. (1973). Subtypes of hepatitis B antigen, clinical relevance. Ann. intern. Med., 79, 894-896.

Martini, G. A., Strohmeyer, G., and Sodomann, C. P. (1972). Die panarteritis nodosa bei chronischer hepatitis mit Australia- antigen-nachweis. Dtsch. med. Wschr., 97, 642-645.

Nowoslawski, A., Krawczynski, K., Brzozko, W. J., and Madalinski, K. (1972). Tissue localization of Australia immune complexes in acute and chronic hepatitis and liver cirrhosis. Amer. J. Path., 68, 31-56.

Popper, H., and Mackay, I. R. (1972). Relation between Australia antigen and autoimmune hepatitis. Lancet 1, 1161-1164.

Prince, A. M., Brotman, B., and Ikram, H. (1972). Hemagglutination assay: subtyping by hemagglutination inhibition: an ultrasensitive identity test for HB antigen. In Hepatitis and Blood Transfusion, edited by G. N. Vyas, H. A. Perkins, and R. Schmid,pp. 147-154. Grune and Stratton, New York.

Prince, A. M., Brotman, B., Jass, D., and Ikram, H. (1973). The specificity of the direct solid-phase radioimmunoassay for detection of hepatitis-B antigen. Lancet, 1, 1346-1350.

Prince, A. M., and Trepo, C. (1971). Role of immune complexes involving $\mathrm{SH}$ antigen in pathogenesis of chronic active hepatitis and polyarteritis nodosa. Lancet, 1, 1309-1312.

Trepo, C. G., and Thivolet, J. (1970a). Antigène australien, hépatite á virus et périartérite noueuse. Presse med., 78, 1575 .

Trepo, C. G., and Thivolet, J. (1970b). Hepatitis associated antigen and periarteritis nodosa (PAN). Vox Sang. (Basel), 19, 410-411.

Trepo, C. (1971). Hepatite virale, antigén australien et périartèrite noueuse. These Medecine, Lyon Nord, 1971.

Trepo, C., Thivolet, J., and Lambert, R. (1972a). Four cases of periarteritis nodosa associated with persistant Australia antigen. Digestion, 5, 100-107.

Trepo, C. (1972). Virus de l'Hepatite B et périartèrite noueuse. Nouv. Presse méd., 1, 1879-1881.

Trepo, C. G., Thivolet, J., and Prince, A. M. (1972). Australia antigen and polyarteritis nodosa. Amer. J. Dis. Child, 123, 390-392.

Trepo, C. Trepo, D., Ortiz, J. P., Monier, J. C., and Sepetjian, M. (1973). L'antigen de l'hepatite B, interêt clinique de sa detection par un dosage radioimmunologique en phase solide. Nouv. Presse méd., 2, 2339-2340.

Ziff, M. (1971). Viruses and the connective tissue diseases. Ann intern. Med., 75, 951-958.

Zuckerman, A. J. (1970). Electron microscopy and immune electrono음 microscopy. Bull. Wld Hlth Org., 42, 975-977.

Zuckerman, A. J. (1972). The fine structure of antigens. In Hepatitice associated Antigen and Viruses, pp. 77-75. North-Holland? Amsterdam. 